\title{
MAREK KLUZ \\ Odkrywanie sensu choroby i cierpienia w kontekście nowych wyzwań
}

Temat choroby i cierpienia zawsze należał do grupy najpoważniejszych i problematycznych. Nic dziwnego, gdyż doświadczenia te poddają często próbie życie ludzkie i wiarę. Choroba i cierpienie mają swój wymiar społeczny, psychologiczny, medyczny, biologiczny, a także moralny, religijny, są bowiem jakby stacją drogi krzyżowej, mimo powszechnemu traktowaniu choroby i cierpienia jako zła ograniczającego ludzką sprawność.

We wszystkich kulturach i każdym czasie starano się ulżyć ludziom chorym i cierpiącym, a także wytłumaczyć sens choroby i cierpienia. Wydaje się, że we współczesnym świecie ten wielki i wciąż niewyczerpany temat ludzi i chrześcijański domaga się niejako na nowo pogłębionej analizy, a wszystko ze względu na wciąż pojawiające się nowe wyzwania i problemy. Dlatego celem niniejszej publikacji będzie próba odczytania sensu choroby i cierpienia od strony personalistycznej, moralnej i religijnej, w perspektywie obecnego czasu.

\section{Personalistyczne odkrywanie i przeżywanie choroby}

Każdy człowiek niezależnie od bogactwa i pozycji społecznej, wcześniej czy później, przechodzi przez chorobę, a także doświadcza cierpienia ${ }^{1}$. Niektórzy

Marek KLUZ, ks. dr hab., adiunkt przy Katedrze Teologii Moralnej i Duchowości Wydziału Teologicznego - Sekcja w Tarnowie Uniwersytetu Papieskiego Jana Pawła II w Krakowie, sekretarz WTST. e-mail: $\underline{\text { mkluz@op.pl }}$

${ }^{1}$ Od najdawniejszych czasów przy definiowaniu choroby wykorzystywano przeciwstawne założenia, starając się ustalić wyraźną granicę między zdrowiem i chorobą, czyli między zjawiskami prawidłowymi a nieprawidłowymi, zmienionymi, tj. patologicznymi. Więcej por. W. D u rda: Chrześcijańska postawa wobec cierpienia. Kraków 1998 s. 43-44. 
doświadczają bólu fizycznego związanego z wypadkiem, chorobą, inni bólu psychicznego związanego ze śmiercią bliskiej osoby ${ }^{2}$. Jak różne są owe doświadczenia, tak jednocześnie różne są ludzkie reakcje na ból. Nie pozostawia w nas śladu ból ostry i krótkotrwały, natomiast, gdy jest intensywny i długotrwały, staje się doświadczeniem. Może wówczas zdezorganizować psychikę, zburzyć równowagę, zamknąc na innych ludzi, wpłynąć na życie zawodowe, społeczne, zablokować pragnienia, nadać specyficzną barwę emocjom i uczuciom, zakłócić myślenie, nawet doprowadzić do kryzysu wiary. Pokazuje to doskonale, że ból fizyczny związany $\mathrm{z}$ chorobą niejednokrotnie przekracza ciało człowieka, dotykając duszy $^{3}$. Trzeba jednak wspomnieć, że ból jest samoobroną, pożytecznym objawem, znakiem ostrzegającym przed grożącym niebezpieczeństwem, systemem alarmowym, po prostu ,dzwonkiem" ". Choroba jest nie tylko biologicznym zaburzeniem funkcji narządu, lecz jednocześnie procesem o szerokim znaczeniu pedagogiczno-psychologicznym, dotyka całego człowieka, więc i jego człowieczeństwa ${ }^{5}$. Dolegliwość spotyka człowieka, który ma zazwyczaj pewne doświadczenie, określone cechy, zalety i wady, również uzdolnienia, zainteresowania, sukcesy i coraz to nowe marzenia. Nic więc dziwnego, iż często wielkość choroby uzależniona jest od niemożności realizowania tych marzeń, dążeń, powołań życiowych. Choroba, szczególnie niebezpieczna, jest w pierwszej kolejności wstrząsem dla człowieka nią dotkniętego i jego najbliższych, a nierzadko również dla otoczenia. Oprócz bólu fizycznego w chorobie dochodzi cierpienie psychiczne, które może objawiać się w postaci bardzo dojmujących i niekiedy dolegliwych przeżyć. Mianowicie:

- Bolesne doświadczenie stanu swej ograniczoności i fizycznego przemijania. Choroba staje się katastrofą, gdyż przerywa nagle zewnętrzną aktywność, a szczególnie, gdy przykuwa do łóżka na dłuższy czas, co jest równoznaczne z odcięciem od świata i dominującą samotnościąa .

- Przeżywanie swojej samotności. Wiąże się z bezczynnością, oderwaniem od obowiązków i świata. Owo doświadczenie samotności może przejawiać się w dwojaki sposób: jako błogosławieństwo będące okazją do refleksji nad sobą oraz

${ }^{2}$ Por. P. T. de Ch ard i n: $O$ szczęściu, cierpieniu, miłości. Tłum. W. S u k i e n n i ck a. Warszawa 1981 s. 88. Por także: Z. S z o s t k i e w i c z: Vademecum duszpasterza chorych. Warszawa 1993 s. 91.

${ }^{3}$ Por. L. S a n d r i n: Wobec cierpienia: zrozumieć, przyjąć, wyttumaczyć cierpienie. Tłum. K. $\mathrm{K}$ a m iń s k a. Kielce 2000 s. 13-15.

${ }^{4}$ Por. szerzej: W. D u rd a: Chrześcijańska postawa wobec cierpienia..., dz. cyt., s. 56-57. Por. także: L. K o wa lc zy k: Lekarz wobec cierpienia $i$ śmierci człowieka. W: Cierpienie i śmierć. Red. A. J. N o w a k. Lublin 1992 s. 165.

${ }^{5}$ Por. W. D u r d a: Chrześcijańska postawa wobec cierpienia..., dz. cyt., s. 44 oraz 50-51. Por. także: L. S a n d r i n: Wobec cierpienia..., dz. cyt., s. 85-86.

${ }^{6}$ Por. B. Hä ri n g: Nauka Chrystusa. Teologia moralna. T. 3. Tłum. J. K 1 e n o w s k i. Poznań 1963 s. 192. 
wiarą i jako źródło udręki; chory jest samotny z przymusu, więc koncentruje się nad sobą i swoją chorobą, do której sprowadza także swe zainteresowania, działania i wszelakie troski. Lecz nie musi tak być, bo poprzez swoje cierpienie i chorobę może zrozumieć innych chorych?

- Doznanie stanu niemocy związanej z uzależnieniem się od innych. Chory boleśnie odczuwa swą niedołężność i przymus oddania się pod opiekę w cudze ręce $^{8}$. Wówczas dominuje przekonanie, że jest ciężarem dla otoczenia. Dręczy się tą myślą, niekiedy bezpodstawną. Zdarza się, że w następstwie chory odcina się nawet od najbliższych, by ukryć swój stan ${ }^{9}$.

- Odczuwanie odmienności zainteresowań. Chory odcina się od ludzi, ponieważ wydaje się mu niemożliwym nawiązanie porozumienia, kontaktu z innymi, szczególnie ze ,światem młodych”. Według niego, jego cierpienie jest niezrozumiałe dla innych i przytacza go ciężar życia oraz bogactwo doświadczeń, które powinno raczej stać się pociechą ${ }^{10}$.

- Doświadczenie kruchości i nietrwałości egzystencji. Chory czuje się jak wyrzucony siłą z biegu życia, które dalej toczy się swoim torem ${ }^{11}$. Uświadamia sobie również, że nie jest niezastąpiony, a świat może istnieć bez niego. Wtedy staje się zrezygnowany, buntuje się wewnętrznie. Odzywa się w nim dramatyczne pragnienie dokonania jeszcze czegoś w życiu. Chce być zdrowy i żyć normalnie wykonując swoje obowiązki ${ }^{12}$.

Lekarz jest obecny w trudnym procesie choroby, przed którym staje człowiek obarczony nią, szczególnie, gdy jest ciężka i przewlekła. Uczestniczy w tych przeżyciach, staje się powiernikiem i musi być przede wszystkim człowiekiem ${ }^{13}$ w spotkaniu z chorym i cierpiącym, na wzór Samarytanina ${ }^{14}$. Postawa lekarza, jego podejście, ma także wpływ na zdrowie psychiczne i moralne pacjenta, więc oddziałuje na stopień nabycia umiejętności chorowania. Nadto powinien pamiętać, że każdy choruje inaczej, więc nie ma schematów chorowania ani leczenia i najważniejsze jest indywidualne podejście ${ }^{15}$.

\footnotetext{
${ }^{7}$ Por. Z. S z o s t k i e w i c z: Vademecum pacjenta. Warszawa 1992 s. 72-74.

${ }^{8}$ Często chory odczuwa wówczas upokorzenie. Por. Z. S z o s t ki e w i c z: Vademecum pacjenta..., dz. cyt., s. 56-57.

${ }^{9}$ Por. P. T. de C h a r d i n: O szczęściu, cierpieniu, miłości..., dz. cyt., s. 79-80.

${ }^{10}$ Por. L. Sandrin: Wobec cierpienia..., dz. cyt., s. 73-75.

${ }^{11}$ Por. tamże s. 89.

12 Por. S. Ole j n i k: Teologia moralna życia osobistego. Włocławek 1999 s. 420-421. Por. także: J. D e c y k: Chrześcijański wymiar choroby i cierpienia. „Homo Dei”. R.1993 nr 3 s. 70-72; B. H ä r i n g: Nauka Chrystusa..., dz. cyt., s.192.

${ }^{13}$ Por. J a n P a w e 1 I I: List Apostolski Dolentium hominum. Watykan 1985 nr 2.

${ }^{14}$ Por. J a n P a w e ł II: Do chorych i cierpiacych. Kraków 2000 s. 25.

${ }^{15}$ Por. L. K o w a l c z y k: Lekarz wobec cierpienia i śmierci człowieka, dz. cyt., s. 166-167.
} 
Choroba jest często bodźcem wyzwalającym mechanizmy wychowawcze i człowiek otwiera się na nowe możliwości poznawcze siebie, jak również na nowe widzenie siebie i innych. Choroba staje się twórczym czynnikiem rozwoju własnej osobowości, jest umiejętnie przeżywana i traktowana jako wartość, źródło łaski, ale oczywistością jest, że takie myślenie nie pojawia się już w momencie zachorowania. Chorowanie bowiem jest procesem. Można wyróżnić w tym miejscu następujące etapy ${ }^{16}$ : zaskoczenie, poszukiwanie równowagi, uwolnienie się od uzależnień chorobowych.

Na pierwszym etapie zaskoczenia - zdziwienia faktem zachorowania człowiek przechodzi w oszołomienie, potem w oczekiwanie na diagnozę i leczenie. W tym czasie dominuje niepokój, rozdrażnienie. Stres łączy się $\mathrm{z}$ dolegliwościami ${ }^{17}$. Zaskoczenie jest widoczne nie tylko u chorego, ale również w jego rodzinie. Zaskoczeni są niejednokrotnie współpracownicy, znajomi, przyjaciele, co przeradza się u nich w zażenowanie w relacjach do chorego. Dotknięty chorobą człowiek doskonale wyczuwa zawstydzenie otoczenia i rodzi się w nim chęć ucieczki, jest również skłonny do pochopnych, nieprzemyślanych decyzji. Ten pierwszy etap charakteryzuje się koniecznością pokonania cierpienia i zmiany elementów zaskoczenia na elementy pogłębiające i scalające wewnętrznie ${ }^{18}$;

$\mathrm{Na}$ etapie poszukiwania równowagi u chorego zaczyna mijać napięcie związane $\mathrm{z}$ zaskoczeniem, a dominować rozsądek, myśl, refleksja. Chory przechodzi do etapu szukania wyjścia $\mathrm{z}$ trudnej sytuacji. Poszukiwanie może pójść w trzech różnych kierunkach: negatywnym, nijakim i pozytywnym.

W sensie negatywnym chory zachowuje się jak społeczny pasożyt. Wykorzystuje miłość i życzliwość ludzką, przepisy, pieniądze oraz przywileje do egoistycznych celów. Kosztem innych ludzi, za wszelką cenę chce osiągnąć „równowagę" zwaną „urządzeniem się" dzięki chorobie, zazwyczaj jest złośliwy i zirytowany, wszystko go prowokuje, trudno z nim wytrzymać, jest to najtrudniejszy etap dla rodziny chorego, lub chory biernie akceptuje chorobę oraz biernie przyjmuje propozycje leczenia i rehabilitacji, staje się obojętny na sprawy innych, izoluje się nawet od najbliższych, byle mieć „święty spokój”. Reprezentuje wówczas postawę antyspołeczną ${ }^{19}$.

W sensie nijakim chory kieruje się dewizą ,jakoś to będzie", nie ma określonego celu, wszystkie jego dążenia i myśli można określić przymiotnikiem ,jakiś”. Nie ma konkretnych wartości, które chce osiągnąć, lecz są ,jakieś” tam, czyli nijakie. W obliczu tego wszystkiego, jego równowaga i on sam staje się nijaki. W rezultacie chorzy nie widzą możliwości dalszego rozwoju, gubią się,

\footnotetext{
${ }^{16}$ Por. Z. S z o s t k i e w i c z: Vademecum duszpasterza chorych..., dz. cyt., s. 21-27.

${ }^{17}$ Por. Z. S z o s t k i e w i c z: Vademecum pacjenta..., dz. cyt., s. 52-53.

${ }^{18}$ Por. C. K e b e r s: Jak mówić o cierpieniu i śmierci?. Kraków 1994 s. 70.

${ }^{19}$ Por. tamże s. 71.
} 
trwają w niewiedzy przez co ciężar choroby staje się większy, a więc i trudniejszy do udźwignięcia, w następstwie traktowany jako życiowa porażka.

W kierunku pozytywnym chory zmierza ku zharmonizowaniu, uspokojeniu oraz opanowaniu siebie. Swe działania zawsze stara się przemyśleć tak, aby jego dążenia miały cel i sprzyjały odzyskaniu zdrowia, a co za tym idzie, powrotowi do pracy, realizacji swego życiowego powołania, często jeszcze mimo choroby. U człowieka poszukującego równowagi w sposób pozytywny dominuje filozoficzny sposób myślenia, gdyż chory snuje refleksje nad sensem i celem życia, a także zastanawia się nad własnym systemem wartości ${ }^{20}$. Takie działanie i sposób myślenia działa wręcz uspokajająco na otoczenie chorego. Niejednokrotnie zdarza się, że wykorzystując pozytywnie swoją chorobę dana osoba potrafi pomóc innym chorym, jawnie czy anonimowo, dojrzewać osobowo do walki $\mathrm{z}$ choroba.

Trzecie etap czyli uwolnienie się od uzależnień chorobowych osiągają tylko i wyłącznie ci, którzy nauczyli się chorować, a w konsekwencji uwolnili się od ciężarów choroby i nie stawiają jej już w centrum swojej uwagi oraz działań. Jeżeli chodzi o relacje międzyosobowe, to człowiek spotykając się z taką osobą nie widzi w ogóle jej choroby, a jedynie wszechstronną aktywność, bogactwo myśli i ciekawych treści. Chorzy na tym etapie wyzwalając się od uzależnień chorobowych, uwalniają się równocześnie od egoizmu i mają bardzo silne oddziaływanie na innych ${ }^{21}$.

Etapy bywają trudne i niebezpieczne, ale dobrze jest je znać. Często chorzy zatrzymują się na jednym z nich nie mogąc „ruszyć” dalej. Efektem jest wpadanie w złość prowadzącą do nerwicy, pesymizmu i załamań, aż po rozpacz, niszcząc po drodze wszystko i wszystkich, nie umiejąc reagować dobrem. Często mówi się, że choroba może człowieka złamać albo doprowadzić do dojrzałości. Właśnie umiejętność tworzenia dobra, powinna być zarazem celem i skutkiem prawidłowego przeżywania choroby ${ }^{22}$. W podobny sposób przez proces rozwoju przechodzi osobowość, myślenie ludzkie, nim zacznie podchodzić do choroby jako czyniącej człowieka dojrzalszym.

Chorowanie jest nieodłączną cechą człowieczeństwa, a mimo to często słyszy się wyrok: „cierpi za swoje grzechy”. Chrystus dał nam wyraźną odpowiedź, iż tak nie jest, w perykopie o uzdrowieniu niewidomego od urodzenia. Odpowiedź Jezusa na pytanie uczniów: Rabbi, kto zgrzeszyt, że się urodził niewidomym - on czy jego rodzice? nie pozostawia wątpliwości: Ani on nie zgrzeszyt, ani

\footnotetext{
${ }^{20}$ Por. Z. S z o s t k i e w i c z: Vademecum pacjenta..., dz. cyt., s. 53.

${ }^{21}$ Por. tamże, s. 54 oraz s. 96-98. Do grona tych, którzy umiejętnie przyjęli chorobę i uczynili z niej narzędzie walki o lepszy świat należą m.in. K. K. Baczyński, R. C z a c k a, F. R o o s e v e 1 t. Por. Z. S z o s t k i e w i c z: Swiadkowie Ewangelii cierpienia. Warszawa 1997 s. 86-88.

${ }^{22}$ Por. J a n P a w e 1 I I: Do chorych i cierpiacych..., dz. cyt., s. 7.
} 
rodzice jego, ale [stało się tak], aby się na nim objawity sprawy Boże (J 9,1-3). Pytanie o zależność pomiędzy winą a chorobą rodzi się jednak w niejednej głowie. Gdyby takowa zależność istniała, ukazywałaby Boga nieżyczliwego, który odczuwa satysfakcję w ludzkim cierpieniu. Jest to fałszywy obraz Boga. Bóg Biblii nie pragnie ani cierpienia ani śmierci. Człowiek sam przez nieposłuszeństwo, przez nadużycie wolności ściągnął na ludzkość cierpienie i śmierć (to nie stanowi osobistego grzechu) ${ }^{23}$. Bóg Miłosierny wyciągnął jednak swą ratującą dłoń i zesłał światu swego Syna, który jest Zbawicielem człowieka ${ }^{24}$. Choroby, w należytym rozumieniu, ujawniają prawdę o kruchości naszego życia i tego wszystkiego, co czynimy. Wypowiedziane po chrześcijańsku „tak” w stosunku do choroby, jest już w rzeczywistości, jakimś „tak” w stosunku do życia wiecznego, któremu choroba mocą śmierci i zmartwychwstania Chrystusa ma służyćc ${ }^{25}$. Chorobę można traktować jako narzędzie do osiągnięcia świętości, a jednocześnie jako cenę, którą ponosi się za ponowną ewangelizację świata, dlatego chory jest drogocenna perła dla wszystkich ${ }^{26}$. Chorych Bóg miłuje w szczególny sposób. Chorzy, zwłaszcza nieuleczalnie są traktowani inaczej niż zdrowi, jak oddzielna kategoria. Dzieje się tak, gdyż dzisiaj nie rozumie się wartości cierpienia, wykreślając chorych poza margines. A chory może dać innym wiele dobra, przede wszystkim może dać światu świadectwo czym jest cierpienie dla chrześcijan. Cierpienie jest szczególnym darem od Boga, szczególnym Bożym miłowaniem człowieka, który właśnie w chorobie i cierpieniu staje się bardziej podobny do Jego Syna ${ }^{27}$.

Ważną rolę w chorobie i cierpieniu odgrywa Kościół, który poleca chorych cierpiacemu i uwielbionemu Panu, aby ich podźwigną i zbawit, a nadto zachęca ich, aby taczac się z Męka i śmiercia Chrystusa przysparzali dobra Ludowi Bo$\dot{z} e m u^{28}$. Te słowa Soboru Watykańskiego II tłumaczył Jan Paweł II w ten sposób, że wszystkim chorym i cierpiącym służy Kościół powołany do działalności duszpasterskiej. Kościół daje odpowiedź na pytania delikatne i nieuniknione rodzące się w sercu człowieka, a w szczególności ukazuje Chrystusa niosącego pociechę i będącego źródłem niezawodnej nadziei. Chory ma w Kościele specjalną i specyficzną rolę, gdyż jest w nim obecny Chrystus. Kapłan oraz osoby pomagające

${ }^{23}$ Por. KKK 396-401 oraz 417-420.

${ }^{24}$ Por. tamże nry $1503-1505$.

${ }^{25}$ Por. J. P i e g s a: Człowiek - istota moralna. T. 3. Opole 2000 s. 193-194. Por. także: J. D e c y k: Chrześcijański wymiar choroby i cierpienia..., dz. cyt., s. 72-73; J. K a l n i u k: Wizja cierpienia w nauczaniu Jana Pawła II. W: Człowiek droga Kościoła. Moralne aspekty nauczania Jana Pawta II. Red. K. G r y z. Kraków 2004 s. 353 i 355.

${ }^{26}$ C. L u b i c h: Dlaczego mnie opuściteś? Cierpienie w świetle duchowości jedności. Kraków 2000 s. $109-111$.

${ }^{27}$ Por. tamże.

${ }^{28}$ Sobór Watykański II: Konstytucja dogmatyczna o Kościele Lumen gentium. W: Sobór Watykański II: Konstytucje. Dekrety. Deklaracje. Poznań 1967 nr 11. 
mają szczególne zadanie ${ }^{29}:$ pomóc odkryć choremu swoistą misję, tj. łączyć się w swym cierpieniu z cierpiącym Chrystusem poprzez modlitwę i ofiarę cierpienia za dobro całego Kościoła i w ten sposób współpracować w dziele zbawienia świata ${ }^{30}$.

\section{Religijno-moralne odkrywanie i przeżywanie cierpienia}

Choroba i cierpienie są sobie bardzo bliskie, często nierozerwalnie łączą się ze sobą. Chorobą zajmuje się medycyna, która jako nauka i zarazem sztuka leczenia nieustannie poszukuje odpowiednich metod przeciwdziałania, czyli terapii. Natomiast cierpienie jest tajemnicą wykraczającą poza to, co rozpoznaje medycyna, gdyż jest czymś więcej, niż odczuwaniem bólu, czymś rozleglejszym, bardziej zróżnicowanym i wielowymiarowym. Zwrócił na to szczególną uwagę Jan Paweł II pisząc: Człowiek cierpi na różne sposoby, nie zawsze objęte przez medycyne, $w$ jej nawet najdalszych rozgatęzieniach. Cierpienie jest czymś bardziej jeszcze podstawowym od choroby, bardziej wielorakim, a zarazem głębiej jeszcze osadzonym w całym człowieczeństwie ${ }^{31}$. Papież Jan Paweł II mówił także o potrzebie rozróżnienia cierpienia fizycznego od cierpienia moralnego jako, że człowiek jest istotą dwoistą, cielesną i duchową. Jeżeli podmiotem cierpienia staje się ciało, mówimy wówczas o bólu, cierpieniu fizycznym, a jeżeli „boli dusza", to jest to cierpienie moralne, nie mniej rozległe czy mniejsze od bólu fizycznego. Jednak zdaje się być mniej zidentyfikowane i mniej objęte terapią ${ }^{32}$.

Cierpienie jest tym wspólnym światem przė̇yć, gdzie spotykaja się wszyscy wielcy $i$ mali, biedni i bogaci, wierzacy i niewierzacy, panujacy i poddani... ${ }^{33}$ słowa te doskonale ilustrują fakt, że cierpienie jest nieodłącznym składnikiem życia, które trzeba zaakceptować; jest zjawiskiem powszechnym. Cierpienie bardzo często utożsamiane jest z chorobą oraz bólem fizycznym i dlatego z nimi identyfikowane, toteż nic dziwnego, że tematy choroby i cierpienia niejednokrotnie przeplatają się ze sobą. W bólu i cierpieniu widoczne są różne współzależności. Cierpienie jest bardziej zawiłe, złożone, bo wiąże się z życiem wewnętrznym, duchowością człowieka. Ból wiąże się ze sferą biologiczną i psychiczną -

\footnotetext{
${ }^{29}$ Por. C. K e b e r s: Jak mówić o cierpieniu i śmierci... dz. cyt., s. 30-35.

${ }^{30}$ Por. J a n P a w e 1 I I: Uświęcać czas choroby. Do Papieskiej Rady ds. Duszpasterstwa Stużby Zdrowia (21.01.2005). W: Sprawy rodziny. Whołdzie Janowi Pawłowi Wielkiemu Papieżowi rodzin. „Kwartalnik Duszpasterstwa Rodzin”. T. 70: 2005 nr 2-3. Por. także: J a n P a w e 1 I I: Wielka wartość modlitwy i cierpienia. Do chorych i pielgrzymów (11.02.2005). W: Sprawy Rodzi$n y \ldots$, dz. cyt., $\mathrm{nr} 3$.

${ }^{31}$ J a n P a w e 1 I I: List Apostolski Salvifici doloris. Watykan 1984 nr 5 (dalej: SC).

${ }^{32}$ Por. tamże. Por. także: J. D e c y k: Chrześcijański wymiar choroby i cierpienia..., dz. cyt., s. 70; J. K a l n i u k: Wizja cierpienia w nauczaniu Jana Pawła II..., dz. cyt., s. 352; J. R o s 1 o n: Cierpienie. W: Katolicyzm A-Z. Red. Z. P a w la k. Poznań 1982 s. 51n.

${ }^{33}$ J. S z c z e p a ń s k i: Sprawy ludzkie. Warszawa 1980 s. 12.
} 
czujemy ból i jesteśmy świadomi tego. Zrozumienie uświadomionego bólu przenosi go na poziom duszy. Stąd cierpienie jest czymś więcej niż bólem. Poza tym, w związku z powszechnym przekonaniem, ból jest przypisywany całej przyrodzie ożywionej, natomiast cierpienie zarezerwowane jest tylko dla człowieka, przynależy do jego transcendencji, niejako jest na nie 'skazany' i w tajemniczy sposób wezwany, by przerastać samego siebie ${ }^{34}$. Wtedy terminem 'cierpienie' ujmujemy również cierpienie duchowe, w którym mieszczą się samotność, brak kontaktu z otoczeniem, niepewność jutra, śmierć kogoś bliskiego, utrata pozycji, majątku, itp. ${ }^{35}$.

Wyszczególnianie rodzajów cierpienia jest zawsze sprawą umowną i nigdy nie będzie w stanie wyczerpać zagadnienia. Zdaje się bowiem (raczej słusznie), że rodzajów cierpienia jest tyle, ile cierpiących osób. Jednak dla przybliżenia tajemnicy cierpienia, wprowadza się pewne podziały. I tak np., biorąc pod uwagę wymiar istnienia człowieka wyróżniamy:

- cierpienie cielesne rozumiane jako fizyczne, spowodowane przez ból, umiejscowione w konkretnym narządzie, mija wraz z chorobą i daje się złagodzić środkami farmakologicznymi;

- cierpienie duchowe jako lęk, wątpliwość przed sytuacjami i przeżyciami, o skali bardziej rozległej, boleśniej odczuwane niż cierpienie fizyczne, także nie mija szybko, może obejmować przeszłość i przyszłość, mniej rozpoznawane przez medycynę i trudne do znieczulenia ${ }^{36}$;

- cierpienie moralne, bardzo często stosowane zamiennie z cierpieniem duchowym, jego źródłem może być grzech, a wtedy rozróżniamy cierpienie zawinione (skutek grzechu) oraz niezawinione (dopuszczone przez Boga, by osiągnąć dobro duchowe) ${ }^{37}$.

Często na fundamencie tego podziału wyróżnia się: cierpienie religijne właściwe tylko dla człowieka religijnego jako skutek świadomości własnych grzechów, a więc lęk przed potępieniem oraz cierpienie zwierzęce - „nie ludzkie”, bezduszne, któremu towarzyszy ogromna rozpacz i przekleństwo.

Spotkać się można niejednokrotnie z określeniami: cierpienie swoje i cudze. Jest ogromna zależność między nimi, gdyż tylko człowiek, który chorował, doświadczył cierpienia jest $\mathrm{w}$ stanie zrozumieć innego cierpiącego. W przeciwnym razie, zawsze dla człowieka zdrowego, cudze cierpienie jest nieuchwytne. Oprócz tego podstawowego podziału istnieje wiele innych, np. cierpienie krótkie,

${ }^{34}$ Por. SD 2.

${ }^{35}$ Por. W. D u r d a: Chrześcijańska postawa wobec cierpienia..., dz. cyt., s. 36-39 oraz 4146. Por. także: J. K a 1 n i u k: Wizja cierpienia w nauczaniu Jana Pawła II..., dz. cyt., s. 351-352.

${ }^{36}$ Por. L. S a n d ri n: Wobec cierpienia..., dz. cyt., s. 93-94.

${ }^{37}$ Por. B. H är i n g: Nauka Chrystusa..., dz. cyt., s. 192-193. 
przelotne i cierpienie długotrwałe, cierpienie dziecka i cierpienie starca, sensowne i bezsensowne, egzystencjalne i zwykłe, konieczne i zbędne, błahe i dotkliwe, itd. Stres również jest pewnym cierpieniem, powstają wtedy bolesne okoliczności, które powinniśmy bez reszty oddać Jezusowi, który Jest naszym Jedynym Dobrem $^{38}$.

Poszukiwanie sensu cierpienia jest niezwykle trudne, a jednocześnie konieczne, gdyż człowiek potrafi znieść bardzo dużo, jeśli tylko przekona się o sensowności i pozna cel ${ }^{39}$. Zazwyczaj pierwszy etap cierpienia zaskakuje człowieka i działa destrukcyjnie, odbiera siłę wewnętrzną i chęć do życia. W drugim etapie chory zamiast zadawać pytanie 'dlaczego muszę cierpieć?', powinien szukać odpowiedzi 'co mogę zrobić z cierpieniem?', gdyż nie pozna genezy cierpienia, które jest tajemnicą, a może na nie spojrzeć perspektywicznie, zastanawiając się „dla kogo i dla czego cierpi?”,40. Wyakcentował to Jan Paweł II pisząc, że cierpienie jest $w$ świecie po to, ażeby wyzwalato miłość, ażeby rodziło uczynki miłości bliźniego, ażeby cała ludzka cywilizacje przetwarzało $w$ »cywilizacje mitości « ${ }^{41}$. Jednocześnie w słowach tych Ojciec Święty uwidacznia trzy istotne wymiary sensu ludzkiego cierpienia: indywidualny, społeczny i ogólnokulturowy ${ }^{42}$.

Cierpienie hartuje człowieka. Podobnie jak w chorobie, również w przypadku cierpienia musi minąc trochę czasu, by umieć je traktować jako coś pozytywnego, przynoszącego dobre owoce. Zazwyczaj, doświadczony cierpieniem człowiek, w pierwszej kolejności, „włącza” mechanizmy obronne psychiki. Wówczas walka z cierpieniem przechodzi przez następujące etapy:

- bunt, który niestety tylko potęguje cierpienie;

- akceptacja iluzoryczna - zepchnięcie bólu do podświadomości, a więc złudne unicestwienie; cierpienie tak tłumione daje o sobie znać jeszcze silniej w nieprzewidzianych momentach; taka walka przez iluzję może przybierać postawę projekcji czyli przerzucania na innych winy za swój stan zdrowia, bezpodstawne oskarżanie kogoś bliskiego; racjonalizacji, a więc wmawiania sobie, że cierpienie jest czymś naturalnym i koniecznym, okłamywanie siebie, a w głębi odczuwanie bezsensowności i buntu, który wybucha rozgoryczeniem; ucieczki - w krainę fantazji, pozorna obojętność, złudna beztroska 'stworzona' przy pomocy narko-

${ }^{38}$ Por. C. L u b i c h: Dlaczego mnie opuściteś..., dz. cyt., s. 21-22.

${ }^{39}$ Por. Z. S z o s t k i e w i c z: Vademecum pacjenta..., dz. cyt., s. 10-11.

${ }^{40}$ Przykładem może być m. in. Św. M ałg or zata Mari a A l a c o qu e, która w cierpieniu łączyła się z Jezusem nieustannie wzbogacając się duchowo (cierpienie i schorzenie wykorzystała do celów wyższych). Por. Z. S z o s t k i e w i c z: Świadkowie Ewangelii cierpienia..., dz. cyt., s. 32-34.

${ }^{41}$ Por. SD 30.

${ }^{42}$ Por. W. D u r d a: Chrześcijańska postawa wobec cierpienia ..., dz. cyt., s. 51-56. 
tyków i alkoholu lub świata telewizji, chory nie umie stanąc z cierpieniem „twarzą w twarz”, zachowanie takiej postawy trwa krótko, bo szybko na nią brakuje sił;

- akceptacja rzeczywista, autentyczna, trudno osiagalna, odczuwalna wewnętrznie, człowiek inaczej zaczyna patrzeć na siebie i swój los, ma charakter czynny, bardzo ważna jest tu motywacja, owa akceptacja może iść w dwóch kierunkach: akomodacji - zmiana ta powoduje zdążanie do spokojnego znoszenia cierpienia oraz asymilacji - korzystanie dodatkowo z cierpienia, by pogłębić życie duchowe ${ }^{43}$.

Często chorzy nazywają cierpienie „uniwersytetem bezindeksowym”, dzięki któremu odkrywają w sobie nowego człowieka, odważnego, cierpliwego, pełnego godności i prostoty, a także nazywają cierpienie „podróżą ubogich”, bo kto nie cierpiał, to tak, jakby nigdy nie podróżował. Cierpienie jest nieszczęściem, gdy traktujemy je jak nieszczęście, a w rzeczywistości może stać się pomyślne i celowe, dla uświadomienia tego mogą posłużyć pozytywne strony cierpienia. Mianowicie:

- zmusza do konfrontacji z naszym wnętrzem, do refleksji nad naszym człowieczeństwem albo do ukształtowania właściwej filozofii życia, toteż człowiek odnajduje siebie i swoją duszę, odradza się moralnie, dlatego często cierpienie zwane jest „chrztem łez”, „czyśćcem miłosierdzia Bożego na ziemi” lub swoistymi rekolekcjami ${ }^{44}$;

- poszerza perspektywę spojrzenia na życie, uczy sztuki życia, wprowadza w pełnię życia;

- uczy realizmu, zmienia „rachunkowość” wartości, tzn. chory uświadamia sobie, że to, co go fascynowało, nie realizowało prawdziwych wartości, toteż dostrzega znikomość i zawodność dóbr materialnych ${ }^{45}$;

- posiada wymiar społeczny, zbliża ludzi do siebie, burzy przedziały ze względu na wiek, bogactwo, wykształcenie ${ }^{46}$;

- jest świadectwem dla ludzi zdrowych jak z pokorą podchodzić do swojego zdrowia, gdyż wolni od cierpień zapominają o prawdzie człowieczeństwa

\footnotetext{
${ }^{43}$ Por. J. M a k s e 1 o n: Z psychologii cierpienia. „Homo Dei”. R. 1987 nr 1 s. 40-46.

${ }^{44}$ Por. W. D u r d a: Chrześcijańska postawa wobec cierpienia..., dz. cyt., s. 72-73

${ }^{45}$ Por. Z. S z o s t k i e w i c z: Vademecum pacjenta..., dz. cyt., s. 10.

${ }^{46}$ Por. J. Cre n sh a w: Cierpienie. W: Słownik wiedzy biblijnej. Red. B. M e t z g e r, M.
} C o o g a n. Warszawa 1996 s. 91. 
i wiecznym powołaniu, a wtedy Bóg daje ósmy sakrament - „sakrament cierpienia”, który zmniejszając radości ziemskie, zwiększa łaskę i radości wieczne ${ }^{47}$;

- daje szansę zdrowym do wypełniania dobrych uczynków ${ }^{48}$;

- wzywa do wypracowania cnoty wytrwałości, która rodzi nadzieję, że cierpienie nie przemoże i nie pozbawi człowieka właściwej godności ani sensu życia ${ }^{49}$.

Chiara Lubich stwierdziła, że są trzy najważniejsze powody istnienia cierpienia: abyśmy wiedzieli, że bez cierpienia nie można zbudować niczego dobrego; abyśmy wiedzieli, że potrzebujemy go dla naszego oczyszczenia; abyśmy wiedzieli, że jakieś dzieło jest Boże, jeśli jest $w$ nim cierpienie ${ }^{50}$. Cierpienie bywa jedyną drogą do Boga i zbawienia. Gdy człowiek zapomina o swoim Stwórcy, On nie rezygnuje $\mathrm{z}$ człowieka, poprzez cierpienie pragnie otworzyć mu oczy i ukazać życie z Bogiem. W ten sposób cierpienie staje się Dobrą Nowiną ${ }^{51}$. Cierpienie bardzo często jest traktowane jako dar, widoczny znak łaski Bożej, jako wyraz szczególnej przyjaźni ${ }^{52}$. Podobnie jak ludziom zdolnym i z dużymi kompetencjami powierza się odpowiedzialne oraz znaczące zadania, tak również na wybranych, zaufanych tylko Bóg zsyła cierpienie ${ }^{53}$.

Moralny i religijny sens cierpienia odkrywamy nade wszystko dzięki cierpieniu Chrystusa, który jest dla nas wzorem. Mógł wybrać tysiąc innych dróg, by zbawić człowieka, ale wybrał cierpienie ${ }^{54}$. W świetle Chrystusowego Krzyża, w tajemnicy Odkupienia cierpienie ma swój najwyższy i najpewniejszy punkt odniesienia. Ofiara krzyżowa jest szczytem miłości, wzorem zjednoczenia z Bogiem Ojcem. Podkreśla to wielokrotnie Święty Paweł: Bądźcie więc naśladowcami Boga, jako dzieci umilowane, i postepujcie droga miłości, bo i Chrystus was umiłowat $i$ samego siebie wydat za nas $w$ ofierze $i$ dani na wdzięczna wonność Bogu (Ef 5,1-2). Bóg dał nam swojego Syna przez ofiarę krzyża, by zgła-

${ }^{47}$ Por. W. D u r d a: Chrześcijańska postawa wobec cierpienia ..., dz. cyt., s. 66-67. Por. także: J. Kalniu k: Wizja cierpienia w nauczaniu Jana Pawła II..., dz. cyt., s. 368-371 oraz 376-379.

${ }^{48}$ Por. SD 30.

${ }^{49}$ Por. J. K a l n i u k: Wizja cierpienia w nauczaniu Jana Pawła II..., dz. cyt., s. 353. Por. także: Z. S z o s t k i e w i c z: Vademecum pacjenta..., dz. cyt., s. 40-42.

${ }^{50}$ C. L u b i c h: Dlaczego mnie opuściteś?...., dz. cyt., s. 27-29.

${ }^{51}$ Por. Sobór Watykański II: Konstytucja duszpasterska o Kościele w świecie współczesnym Gaudium et spes. W: Sobór Watykański II: Konstytucje..., dz. cyt., nr 22. Por. także: KKK 1501.

${ }^{52} \mathrm{O}$ błogosławieństwie cierpienia mówił nam sam Jezus. Por. Mt 5,4.10-12. Szczęśliwość cierpienia można zrozumieć tylko wtedy, gdy uznamy, że nasze życie nie kończy się na ziemi, ale jest zwrócone ku szczęściu wiecznemu. Por. Jan Paweł II: Do chorych i cierpiących..., dz. cyt., s. 22. Por. także: C. K e b e r s: Jak mówić o cierpieniu..., dz. cyt., s. 20.

${ }^{53}$ Por. R. W a 1 d e r a: List do chorej. „Apostolstwo Chorych”. R. 1968 nr 39 s. 2.

${ }^{54}$ Por. C. L u b i c h: Dlaczego mnie opuściteś?..., dz. cyt., s. 11-12. 
dzić grzechy świata. Przez krzyż Chrystus sprawił, że człowiek nie zginą1 ${ }^{55}$. Dzięki Chrystusowi cierpienie zyskało nowy wymiar i nowy porządek, gdyż zostało związane z miłością. Poznanie prawdziwej odpowiedzi na pytanie „dlaczego cierpienie?” jest możliwe tylko wtedy, gdy skierujemy się właśnie na objawienie Bożej Miłości, ona jest przecież źródłem wszystkiego, co istnieje. Mitość jest też najpetniejszym źródłem sensu cierpienia, które pozostaje zawsze tajemnica (...). Chrystus pozwala nam wejść w tajemnice i odkryć »dlaczego cierpienie«, o ile jesteśmy zdolni pojać wzniostość miłości Bożej (...). Miłość jest też najpetniejszym źródtem odpowiedzi na pytanie o sens cierpienia. Odpowiedzi tej udzielit Bóg człowiekowi w Krzyżu Jezusa Chrystusa ${ }^{56}$. Dalej uświadamia nam św. Paweł: Teraz raduję się $w$ cierpieniach za was $i$ ze swej strony w moim ciele dopetniam braki udręk Chrystusa dla dobra Jego ciała, którym jest Kościót (Kol 1,24). Bardzo wyraźnie słowa Apostoła wytłumaczył Jan Paweł II mówiąc, że charakter twórczy cierpienia Chrystusa sprawia, iż człowiek zawsze może się z Nim związać i w ten sposób dopełnić dzieło Jezusa ${ }^{57}$.

Z powyższych rozważań wynika, że choroba i cierpienie należą do najpoważniejszych problemów, poddających próbie życie ludzkie i wiarę. Człowiek doświadcza w chorobie i cierpieniu swojej niemocy, ograniczeń i skończoności. Będąc specyficznym sposobem ludzkiej egzystencji, choroba i cierpienie umożliwia człowiekowi doświadczenie śmierci i może być pomocą do religijnego i moralnego udoskonalenia jego życia, zwłaszcza gdy wiąże on swoją egzystencję z Bogiem.

Choroba i cierpienie może prowadzić do niepokoju, do zamknięcia się w sobie, czasem nawet do rozpaczy i buntu przeciw Bogu, ale może być także drogą do większej dojrzałości, może pomóc lepiej rozeznać w swoim życiu to, co nieistotne, aby zwrócić się ku temu, co istotne. Postawa życiowa człowieka chorego i cierpiącego zależy od jego nastawienia wewnętrznego, a nade wszystko od otoczenia chorego. Należy więc pamiętać, że nie wystarczy specjalistyczna, medyczna fachowość w podejściu do człowieka chorego i cierpiącego. Człowiek bowiem potrzebuje tu jeszcze innego lekarstwa, na które nie można wypisać recepty. Tym lekarstwem jest spotkanie z drugim człowiekiem na płaszczyźnie czynnej miłości.

Trzeba też zauważyć, że w myśl szerokiej koncepcji zdrowia ludzkiego jako uzdolnienia do realizacji swego życiowego powołania $\mathrm{i}$ to $\mathrm{w}$ jak najpełniejszym wymiarze, największą chorobą współczesności jest brak miłości, jest niezdolność do miłości. Stąd też najważniejszym lekarstwem jest miłość. I tego lekarstwa naj-

\footnotetext{
${ }^{55}$ Por. SD 16, 18.

${ }^{56}$ SD 13.

${ }^{57}$ Por. tamże nr 24. Por. także: J a n P a we 1 I I: Do chorych $i$ cierpiacych..., dz. cyt., s. 23-24.
} 
bardziej potrzebuje współczesny człowiek, a szczególnie potrzebuje go człowiek dotknięty chorobą i cierpieniem. Miłości potrzebuje też współczesna medycyna, bez niej bowiem będzie ona tylko sztuką leczenia, nauką, ale nie będzie posłannictwem, służbą. I o tym należy zawsze pamiętać. 